\title{
Intra-Household Labor Supply, Migration, and Subsistence Constraints in a Risky Environment: Evidence from Rural El Salvador
}

\author{
Timothy J. Halliday ${ }^{*}$ \\ Department of Economics \\ University of Hawaii at Manoa \\ IZA \\ Working Paper No. 09-20R \\ Revised December 16, 2009
}

\begin{abstract}
We use panel data from El Salvador to investigate migration and the intra-household allocation of labor as a strategy for coping with uninsured risk. Consistent with a model of a farm household with a binding subsistence constraint, we show that adverse agricultural productivity shocks increased both male migration to the US and the supply of male agricultural labor within the household in El Salvador. In contrast, after damage sustained from the 2001 earthquakes, female migration from El Salvador declined. This is consistent with the earthquakes increasing the demand for home production. Overall, household responses to uninsured risk appear to be consistent with a simple framework in which household members are allocated to sectors according to their comparative advantage. Finally, we show no evidence that the labor market in El Salvador is capable of helping rural Salvadoran households to buffer the effects of adverse shocks.
\end{abstract}

Keywords: Migration, Labor Supply, Insurance, Intra-Household Allocation, Subsistence Constraints

JEL Codes: J22 J61

\footnotetext{
* This is a substantially revised version of an earlier paper entitled, "Migration, Risk, and the Intra-Household Allocation of Labor in El Salvador." I thank the editor of this journal and two anonymous referees for excellent comments. In addition, I would like to thank Sally Kwak, Ted Miguel, Ilan Noy, Raymond Roberston and seminar participants at the World Bank and IZA Conference on Employment and Development in Bonn, Germany in June, 2007 for useful comments. The usual disclaimer applies. Address: 2424 Maile Way; Saunders Hall 533; Honolulu, HI 96822. Tele: (808) 956 - 8615. E-mail: halliday@hawaii.edu. URL: www2.hawaii.edu/ halliday.
} 
"There are districts in which the position of the rural population is that of a man standing permanently up to the neck in water, so that even a ripple is sufficient to drown him." - R.H. Tawney $(1966)^{1}$

\section{Introduction}

Households in less-developed countries (LDCs) often times live very close to the subsistence level and, at the same time, face a large degree of uninsured risk. In such an environment, an adverse shock such as a loss of livestock or harvest can be devastating. Because of the increased gravity of such events, households often are forced to rely on a menu of risk coping strategies to buffer the event's impact. One possible strategy that has been discussed at length by Barzel and MacDonald (1973) and Scott (1976) is to increase labor supplied to an activity despite lower remuneration. While this is not consistent with a model of neoclassical labor supply with a dominant substitution effect, increased labor supply may be one of the more efficient

\footnotetext{
${ }^{1}$ This quote from Land and Labor in China opens James C Scott's 1976 book The Moral Economy of the Peasant in which he discusses how subsistence concerns can lead to seemingly anomalous outcomes in agrarian societies.
} 
means of keeping the household above the subsistence threshold. Alternatively, the household may reallocate its labor towards better remunerated activities such as working outside of the household. One possible way of doing this is to migrate to areas with better opportunities and then remit back to the household. In this paper, we consider how two risk coping strategies, migration and intra-household labor supply, are used to buffer the effects of uninsured risk among poorer households in rural El Salvador.

It has been long been known that migration plays a crucial role for households in less-developed countries (LDCs). Most obviously, migrant remittances are a crucial source of income. The United Nations Development Program estimated that in the year 2000, remittances contributed 1.75 billion to the GNP of El Salvador (PNUD 2001). In addition, migration is often used as a means of coping with risk. Indeed, there is a nascent, but growing, body of literature in development economics that has shown the importance of migration as both an ex post risk management strategy (Halliday 2006; Yang and Choi 2007) and an ex ante strategy (Paulson 2000; Rosenzweig and Stark 1989).

However, while the literature on "non-market mechanisms" for coping with uninsured risk in LDCs has paid a substantial amount of attention to migration, the use 
of the intra-household allocation of labor has largely been ignored. ${ }^{2}$ In this paper, we add to this literature by investigating not only how the intra-household allocation of labor can be used as a risk coping strategy, but also how intra-household allocations due to, for example, productivity differences can condition the household's migration and labor supply responses to uninsured risk. For example, in a simple model of a farm household, the response of the labor supply of men and women within a household to an exogenous productivity shock will depend on which members are at interior and at corner solutions (which may be consequences of productivity differences among household members). Theoretically, genders who are more likely to be at corner solutions will be less affected than those who are more likely to be at interior solutions. In our empirical analysis, we provide evidence of this.

In addition, we show how much of households' responses to risk in our data are very much consistent with the models discussed in Barzel and MacDonald (1973) and Scott (1976) in which the household is on the verge of falling below the subsistence line. Our data paint a picture in which the household uses a variety of risk

\footnotetext{
${ }^{2}$ This paper contributes to the more general literature on the use of "non-market mechanisms" for coping with uninsured risk in LDCs. Examples of these that have been investigated include transferring funds within villages or families (Townsend 1994; Udry 1994a; Yang and Choi 2007), depleting assets (Paxson 1992; Rosenzweig and Wolpin 1993; Udry 1994b), increasing the labor supply (Kochar 1999), adding household members (Frankenberg, Smith, and Thomas 2003), and migrating (Rosenzweig and Stark 1989; Paulson 2000; Halliday 2006). Our contribution is to further investigate both migration and intra-household labor supply as ex post strategies for coping with risk.
} 
coping methods to deal with adverse events including migration and increased labor supply. More importantly, however, we show that often the household chooses to increase their labor supply in sectors that have been hard hit by productivity shocks. Increased labor supply in the presence of low marginal returns appears to be one way in which the household keeps their head above water.

The balance of this paper is organized as follows. In the next section, we discuss some theoretical considerations. In the two subsequent sections, we discuss our data and empirical findings. Finally, we conclude.

\section{Theory}

We construct a model of migration and intra-household labor supply as a means of ex post risk management in the presence of transactions costs and subsistence constraints. The model is very much inspired by Paxson (1990) who considers portfolio choice in the presence of liquidity constraints and Barzel and McDonald (1973) who consider labor supply in the presence of subsistence constraints.

\subsection{Model Primitives}


There are two time periods: $t \in\{1,2\}$. In each period, the household is endowed with a measure of labor of size one. In periods one and two, labor can be allocated to the South $\left(L_{t}\right.$ for $\left.t \in\{1,2\}\right)$ or the North $\left(M_{t}\right.$ for $\left.t \in\{1,2\}\right)$. We assume that $M_{0}=0$. The marginal returns to labor in the North are given by $w$. In the South, labor is on the farm and the returns to labor are determined by an increasing and concave production function which we denote with $A_{t} F($.$) for t \in\{1,2\}$ where $A_{t}$ is a stochastic productivity shock. We make the normalization that $F(0)=0$. There are costs to Northward migration given by $\tau<w$. We assume that Southward migration is not possible. ${ }^{3}$ In periods one and two, the household consumes a consumption good ( $C_{t}$ for $\left.t \in\{1,2\}\right)$ and leisure $\left(N_{t}\right.$ for $\left.t \in\{1,2\}\right)$. Utility from consumption and leisure is additively separable and is determined by two increasing and concave utility functions denoted by $U($.$) for consumption and V($.$) for leisure.$ The household faces a subsistence constraint and so, we require that $C_{t} \geq \bar{C}$ for $t \in\{1,2\}$. In addition, we assume that there is no savings. However, migration will behave like a storage technology in the sense that it enables the household to transfer utility across periods. Finally, there is no discounting.

This is a model of ex post risk management in which the household first observes $A_{t}$ and then makes their labor allocation and consumption choices for that period. ${ }^{4}$

\footnotetext{
${ }^{3}$ We make this assumption to simplify some of the comparative statics calculations that come later.

${ }^{4}$ In contrast, if we were concerned with risk management ex ante, we would need to be more
} 
Consequently, in the morning of period $t$, the household observes $A_{t}$ and then, in the afternoon, chooses their portfolio $\left\{N_{t}, M_{t}, L_{t}\right\}$. After this, the household consumes for that period. Finally, note that, in the first period, second period returns are unknown..$^{5}$

\subsection{Model Solution}

As in Paxson (1990), we solve the model by backwards recursion. In the morning of the second period, the agent observes $A_{2}$ and inherits $M_{1}$ from the previous period. Based on this information, they make their portfolio choice. Accordingly, their period two indirect utility function is given by

$$
V\left(A_{2}, M_{1}\right)=\max _{\left\{L_{2}, M_{2}, N_{2}\right\}} U\left(C_{2}\right)+V\left(N_{2}\right)
$$

explicit about uncertainty and expectations. For example, Rosenzweig and Stark (1989) argue that marriage is used in India to diversify income streams, which in turn raises the household's ex ante expected utility (i.e., before any shocks have been realized). In this work we only consider decisions that have been made after the realization of the first period shock.

${ }^{5}$ Because of this, the general solution of the model actually does capture elements of both $e x$ post and ex ante risk management. However, to facilitate the exposition, we will only consider a specific case in which there are no ex ante risk management considerations. 
subject to

$$
\begin{aligned}
M_{2}+L_{2}+N_{2} & =1 \\
C_{2} & =A_{2} F\left(L_{2}\right)+w M_{1}+(w-\tau) \Delta M_{2} \\
C_{2} & \geq \bar{C} \\
\Delta M_{2} & \geq 0 .
\end{aligned}
$$

The first constraint is the time constraint. The second is the budget constraint. The third is the subsistence constraint. The fourth says that we do not consider the possibility of Southward migration.

We make the simplifying assumption that $w$ is sufficiently large so that $M_{1}$ will be large enough that the household will choose $L_{2}=0$ and $M_{2}=M_{1} \cdot{ }^{6}$ In other words, Northern wages are high enough that the household can completely finance its second period consumption out of its first period migrant stock. Also, note that if Northern wages are sufficiently large, then the subsistence constraint will not bind in the second period. The second period indirect utility function then simplifies to $V\left(A_{2}, M_{1}\right)=U\left(w M_{1}\right)+V\left(1-M_{1}\right)$

\footnotetext{
${ }^{6}$ We make this assumption to simplifying the following exposition. In addition, because we assume that $F(0)=0$, this eliminates the expectation from the maximand in the first period's maximization program and, thus, any ex ante risk management considerations from the problem.
} 
We now move backwards to period one. In its dusk, the agent observe $A_{1}$ and then makes their portfolio choice. The indirect utility function at this time is

$$
V\left(A_{1}\right)=\max _{\left\{L_{1}, M_{1}, N_{1}\right\}} U\left(C_{1}\right)+V\left(N_{1}\right)+U\left(w M_{1}\right)+V\left(1-M_{1}\right)
$$

subject to

$$
\begin{aligned}
M_{1}+L_{1}+N_{1} & =1 \\
C_{1} & =A_{1} F\left(L_{1}\right)+(w-\tau) M_{1} \\
C_{1} & \geq \bar{C} \\
M_{1} & \geq 0 .
\end{aligned}
$$

For the remainder of this section, we suppose that the first period subsistence constraint binds as this provides us with the most interesting behavior. If we let $\lambda \geq 0$ denote the multiplier on the subsistence constraint for the first period, we can characterize the optimal portfolio choice of a subsistence-constrained household with two equations:

$w U^{\prime}\left(w M_{1}\right)=V^{\prime}\left(1-M_{1}\right)+A_{1} F^{\prime}\left(L_{1}\right) U^{\prime}(\bar{C})+\lambda A_{1} F^{\prime}\left(L_{1}\right)+(\tau-w)\left[\lambda+U^{\prime}(\bar{C})\right]$ 
and

$$
\bar{C}=A_{1} F\left(L_{1}\right)+(w-\tau) M_{1}
$$

Inspection of condition (1) reveals that production and consumption decisions are closely linked. Hence, separation does not obtain in this economy. The reason is the irreversibility of the migration investment which creates frictions in the outside labor market. ${ }^{7}$ For an excellent discussion of the theory and empirics of separation in farm households, we refer the reader to Benjamin (1992)

\subsection{Comparative Statics}

We now consider comparative statics in the model with respect to changes in first period returns: $A_{1}$. First, we note that $\frac{\partial \lambda}{\partial A_{1}}<0$. The reason for this is that better realizations of $A_{1}$ make it less likely that the subsistence constraint will bind in the first period and, hence, will drive $\lambda$ towards zero. Next, we differentiate equations (1) and (2) with respect to $A_{1}$ and solve for $\frac{\partial M_{1}}{\partial A_{1}}$ and $\frac{\partial L_{1}}{\partial A_{1}}$. For first period farm labor in the South, we obtain

$$
\frac{\partial L_{1}}{\partial A_{1}}=\Delta_{1}^{-1}\left[\Lambda_{1}+\Gamma_{1}\right]
$$

\footnotetext{
${ }^{7}$ You can have separation in a model with a binding subsistence contraint and no migration costs. In such a model, the solution in a given period will be $A F^{\prime}(L)=w$ and $\bar{C}=A F(L)+w M$. Clearly, the choice of $L$ does not depend on preferences.
} 
where

$$
\begin{aligned}
\Delta_{1} & \equiv w^{2} U^{\prime \prime}\left(w M_{1}\right) C_{2}+V^{\prime \prime}\left(1-M_{1}\right) C_{2}-A_{1} F^{\prime \prime}\left(L_{1}\right) U^{\prime}(\bar{C})-\lambda A_{1} F^{\prime \prime}\left(L_{1}\right) \\
\Lambda_{1} & \equiv F^{\prime}\left(L_{1}\right) U^{\prime}(\bar{C})+\lambda F^{\prime}\left(L_{1}\right)+[\tau-w] \frac{\partial \lambda}{\partial A_{1}} \\
\Gamma_{1} & \equiv-w^{2} U^{\prime \prime}\left(w M_{1}\right) C_{1}-V^{\prime \prime}\left(1-M_{1}\right) C_{1}+\frac{\partial \lambda}{\partial A_{1}} A_{1} F^{\prime}\left(L_{1}\right)
\end{aligned}
$$

where $C_{1} \equiv \frac{F\left(L_{1}\right)}{[\tau-w]}<0$ and $C_{2} \equiv \frac{A_{1} F^{\prime}\left(L_{1}\right)}{[\tau-w]}<0$. Our assumptions imply that $\Delta_{1}>0$, $\Lambda_{1}>0$, and $\Gamma_{1}<0$. One can interpret $\Lambda_{1}$ as a standard substitution effect; when $A_{1}$ increases leisure becomes more expensive and so the household works more on the farm. The term $\Gamma_{1}$ captures subsistence considerations; here a decrease in $A_{1}$ will push the household below the subsistence line and force it to work more on their farm. If $\Lambda_{1}+\Gamma_{1}<0$, then we will have that $\frac{\partial L_{1}}{\partial A_{1}}<0$, so that the household will work less on their farm despite lower remuneration.

The comparative static for migration is given by

$$
\frac{\partial M_{1}}{\partial A_{1}}=\Delta_{2}^{-1}\left[\Lambda_{2}+\Gamma_{2}\right]
$$


where

$$
\begin{aligned}
\Delta_{2} & \equiv-w^{2} U^{\prime \prime}\left(w M_{1}\right)-V^{\prime \prime}\left(1-M_{1}\right)+A_{1} F^{\prime \prime}\left(L_{1}\right) U^{\prime}(\bar{C}) K_{2}+\lambda A_{1} F^{\prime \prime}\left(L_{1}\right) K_{2} \\
\Lambda_{2} & \equiv-F^{\prime}\left(L_{1}\right) U^{\prime}(\bar{C})-A_{1} F^{\prime \prime}\left(L_{1}\right) U^{\prime}(\bar{C}) K_{1}-\lambda F^{\prime}\left(L_{1}\right)-\lambda A_{1} F^{\prime \prime}\left(L_{1}\right) K_{1}+[w-\tau] \frac{\partial \lambda}{\partial A_{1}} \\
\Gamma_{2} & \equiv-\frac{\partial \lambda}{\partial A_{1}} A_{1} F^{\prime}\left(L_{1}\right)
\end{aligned}
$$

where $K_{1} \equiv-\frac{F^{\prime}\left(L_{1}\right)}{A_{1} F^{\prime}\left(L_{1}\right)}<0$ and $K_{2} \equiv \frac{[\tau-w]}{A_{1} F^{\prime}\left(L_{1}\right)}<0$. Our assumptions imply that $\Delta_{2}>0, \Lambda_{2}<0$, and $\Gamma_{2}>0$. The term, $\Lambda_{2}$, contains both substitution and subsistence effects. First, as the returns to farm labor increase, the household will substitute away from migrants in its portfolio. However, it also contains subsistence effects as well in the sense that one way to mitigate a fall in $A_{1}$ is also to work more in the North. This is enabled by our assumption that $\tau<w$ which implies that migration yields immediate benefits. ${ }^{8}$ If $\Lambda_{2}+\Gamma_{2}<0$, then we will have that $\frac{\partial M_{1}}{\partial A_{1}}<0$, so that the household will rely on migration less when returns to farm labor are higher.

The key insight of this model is that in the presence of subsistence constraints we can observe some behaviors that seem paradoxical. In the model, it is possible

\footnotetext{
${ }^{8}$ This is not an unreasonable assumption. Data from the Mexican Migration Project reveal that the price of a coyote (since 1990) was about $\$ 1300$ (in 1999 dollars) and data from the US census reveal that the average hourly wage for a Salvadoran male in the US is $\$ 5.44$. Accordingly, the yearly income for somebody working 40 hours per weeek for 52 weeks out of the year is about $\$ 11315.2$.
} 
to observe both $\frac{\partial M_{1}}{\partial A_{1}}<0$ and $\frac{\partial L_{1}}{\partial A_{1}}<0$. The first comparative static is intuitive since one would expect that households will migrate in response to lower returns to labor at home. This is consistent with Halliday (2006) and Munshi (2000), for example. However, at the same time that we observe this, it is also possible to observe that the household is working more on the farm despite a low marginal product of labor. This is partly enabled because migration also fulfills a subsistence role in the model as discussed above. To facilitate higher labor supply on the farm and in the North, the household takes a hit in terms of leisure consumption.

\subsection{Home Production and Comparative Advantage}

We conclude the theory section with a discussion of the implications of heterogeneous types of labor, home production and comparative advantage for the household's risk coping strategy. Suppose that each sector $M_{t}$ and $L_{t}$ can be sub-divided into male and female labor $\left(M_{t}^{M}, M_{t}^{F}\right)$ and $\left(L_{t}^{M}, L_{t}^{F}\right)$. Labor productivity is heterogeneous. For males and females, respectively, returns are $\left(w^{M}, w^{F}\right)$ in the North and are $\left(\alpha_{t}^{M} A_{t}, \alpha_{t}^{F} A_{t}\right)$ on the farm in the South. Note that we now decompose productivity in the South into two parts. The first is $A_{t}$ and models stochastic productivity shocks that are common across genders. The second is $\alpha_{t}^{j}$ for $j \in\{M, F\}$ and models non-stochastic gender-specific differences in productivity. In addition, 
suppose that there is a home produced commodity denoted by $H_{t}$ that yields utility $W\left(H_{t}\right)$. This commodity is produced by male and female labor allocated to this sector which we denote by $\left(J_{t}^{M}, J_{t}^{F}\right)$. The home production technology is given by $G\left(J_{t}^{j}\right)$ for $j \in\{M, F\}$. Productivity at home is denoted by $\beta_{t}^{j} B_{t}$ for $j \in\{M, F\}$ and its decomposition is analogous to that for farm production. We make standard assumptions on $W($.$) and G(.) .^{9}$

Due to productivity differences between males and females, the household may be at corner solutions for certain gender-sector combinations. For example, if $\beta_{t}^{F}>>$ $\beta_{t}^{M}$ and $a_{t}^{M}>>\alpha_{t}^{F}$, then we would expect to see that the household allocates no males to home production and no females to the farm. Scenarios such as this have interesting implications for how the household responds to changes in $A_{t}$ and $B_{t}$. Because interior solutions will be characterized by equalities and corner solutions by inequalities, small changes in either $A_{t}$ or $B_{t}$ will tend to affect the gender-sectors that are at an interior allocation more than those that are at corners. This is a hypothesis that we will test.

\footnotetext{
${ }^{9}$ We did not make these generalizations to the model earlier because this would have substantially complicated the comparative statics calculations without adding any additional insights.
} 


\section{Data}

\subsection{BASIS}

Our primary data source is the BASIS Panel from El Salvador which was fielded by the Ohio State University and the Fundación Salvadoreño para el Desarollo Económico y Social (FUSADES) ${ }^{10}$ We employ three waves of the panel that have recall periods of 1997,1999 , and 2001 . The data contain identifiers that enable us to track households across time. Because some key variables were only available for 1999 and 2001, our regressions only use these years. However, the 1997 data was still used in the analysis to construct lags of some of many variables. Finally, for the duration of this paper, we will use the recall periods of 1997, 1999, and 2001 to refer to the panel year, but it is crucial for a proper understanding of our econometrics to bear in mind that these three surveys were fielded in 1998, 2000, and 2002. This is a point that we will discuss further towards the end of this sub-section.

\subsubsection{Migrants}

The BASIS data contain information on the number of migrants within the household. We define a migrant to be any household member who at the time that the

\footnotetext{
${ }^{10}$ For a more thorough discussion of these data including an analysis of panel attrition, we refer the reader to Halliday (2006).
} 
survey was administered was residing in the United States or Canada. ${ }^{11}$ The survey does not distinguish if a specific migrant was residing in the United States or Canada, but we believe that it is reasonable to assume that the vast majority of migrants are residing in the United States. Because of this, for the remainder of the paper we refer to all migrants as residing in the United States. Descriptive statistics on this variable are reported in Table 1.

\subsubsection{Labor Supply Within the Household}

We also employ data on intra-household labor supply. These data come from a component of the BASIS survey that listed numerous household activities and then asked, "Cuánto tiempo trabajó en esa actividad?" or "How much time did he (she) work in that activity?" We employ data for three activities. The first is what we call "field labor." In the survey, this is defined as "Trabajo agrícola para venta o autoconsumo" or "Agricultural work for sale or self-consumption." We call the second "livestock labor," which the survey defines as "Cuidado de animales para venta o autoconsumo" or "Care of animals for sale or self-consumption." 12 Finally,

\footnotetext{
${ }^{11} \mathrm{~A}$ household member is defined as someone who is tied to the family by blood or marriage.

${ }^{12}$ It is important to note that the BASIS survey does not explicitly say that what we define as "field labor" constitutes work such as planting, tending to, and/or harvesting crops. However, the survey does list caring for livestock as an activity separate from what they call agricultural activity. Accordingly, we infer that agricultural labor as defined by the survey does not include hours spent tending to livestock and thus includes primarily activities that involve crops.
} 
we call the third "domestic labor," which the survey defines as "Labores domésticas (preparación de alimentos, limpieza, cuido de niños y enfermos)" which in English is "Domestic labor (preparation of food, cleaning, care of children and the sick)." This survey instrument allowed us to measure hours allocated to these activities at the individual level. We then summed these individual level variables by household to obtain household level variables for hours worked by all female and male family members in each of these intra-household sectors. Descriptive statistics for these variables are reported in Table 1.

\subsubsection{Labor Supply Outside the Household}

We also employ information on labor supply outside of the household. This information comes from a different part of the BASIS survey than the information on labor supply within the household and is not as detailed. This survey instrument works as follows. First, the enumerator asked if a household member worked outside of the household during the survey year. Next, the enumerator asked if the individual worked in the following activities: agriculture, industry, commerce, or service. The industrial category included working in textiles. Given the importance of this industry for El Salvador during this time period, we excluded it from the industry category and used it as an additional category, thus, yielding a total of five sectors. 
Respondents were allowed to list more than one sector. Unfortunately, we do not know the number of hours that the respondent allocated to each sector; we only know whether or not they worked in that sector during the survey year. As with the data on intra-household labor supply, we summed these individual level variables by household to obtain household level variables for the total number of female and male household members that worked in each of these sectors during the survey year. Descriptive statistics for these variables are reported in Table 2.

\subsubsection{Stochastic Shocks}

Our stochastic shocks come from two sources: poor agricultural conditions in 1999 and 2001 and the earthquakes of 2001. These data were not available in the 1997 data. The agricultural shocks are dummy variables indicating income loss from either harvest or livestock loss. ${ }^{13}$ In the 1999 and 2001 panels, $25.99 \%$ of all households reported experiencing at least one agricultural shock. The prevalence of these shocks was slightly higher in the 2001 data, presumably due to a drought that occurred in

\footnotetext{
${ }^{13}$ Due to changes in survey design in the years 1999 and 2001, the construction of the harvest and livestock loss dummies warrants some discussion. In 1999, the household was defined to have experienced a harvest loss if it reported losing all or part of its harvest and that this event caused resulted in a lower household income. In 2001, the household was defined to have experienced a harvest loss if it reported that the value of its harvest was less than normal as a consequence of a drought that occurred in 2001. Unfortunately, because the 1999 survey did not solicit the actual cause of the harvest loss, it is not possible to have comparable measures of harvest losses in 1999 and 2001.
} 
that year. Our earthquake shock is an index corresponding to the (log of) monetary value of damage sustained from two earthquakes that occurred on January 13 and February 13, 2001 which is the beginning of the 2001 recall period. The earthquakes registered 7.6 and 6.6 on the Richter Scale, respectively, and killed a total of 1159 people. It is estimated that the disasters had left over 1 million people without adequate shelter by February 2001 (Nicolás and Olson 2001). Descriptive statistics for these variables are reported in Table 1.

As in Udry (1994a and 1994b), all of the shocks we consider are based on selfreports. Recently some researchers have shied away from using self-reported shocks and instead have relied on variables that are supposedly more exogenous, like rainfall. However, rainfall data do have many disadvantages. For example, in a country as small as El Salvador, there may not be sufficient regional variation. More important, because rainfall data are collected at the regional level by a department or a municipio, this precludes the use of many location dummies and raises concerns about omitted variables. In contrast, the shocks we use vary within geographic units. ${ }^{14} \mathrm{Fi}-$ nally, we provide evidence in this paper and in Halliday (2006) that mitigates many of the endogeneity concerns that have been raised about self-reported shocks. ${ }^{15}$

\footnotetext{
${ }^{14}$ For example, Halliday (2006) provides nonparametric density estimates of earthquake damage within departments and shows that there is considerable intra-regional variation.

${ }^{15}$ For example, in this paper, we conduct falsification tests in which we take the shock from a given year and merge it into the dataset by household for the other year. So, if $y_{01}$ and $y_{99}$ are
} 


\subsubsection{Demographic Variables}

Table 3 provides information on the demographic composition of households in the BASIS data. This demographic information excludes all migrants. The categories in this table were used to construct demographic controls in our regressions.

\subsubsection{Timing of Events in the Survey}

At this point, we discuss the timing of events in our survey as it pertains to the econometric results that we present in the remainder of the paper. The dependent variables that we employ are changes across successive surveys (i.e. the recall periods are either 1997 and 1999 or 1999 or 2001) in the stock of either: the number of migrants in the household, the number of hours allocated to various sectors within the household, or the number of household members allocated to various sectors outside the household. The number of migrants is measured at the point-in-time in which the survey was administered (which was 1998, 2000, and 2002), but the variables on labor supply both within and outside the household measure their quantities during the survey's recall period which is one year (either 1997, 1999, or 2001). The variables on agricultural shocks measure whether or not these events took place at a point during

dependent variables for 2001 and 1999 and $s_{01}$ and $s_{99}$ are the shocks defined analogously, we regressed $y_{01}$ on $s_{99}$ and $y_{99}$ on $s_{01}$ to test for false treatments. In addition, in Halliday (2006), we investigated if non-random panel attrition biased our results (in Table 6), tested if the shocks were predicted by baseline household characteristics (in Table 10), and conducted falsification tests (in Table 11). Each of these tests confirmed the exogeneity of the variables. 
the recall period (either 1999 or 2001) and the earthquake shock variable measures the damage of events that occurred in January and February of 2001. Now, consider the change in migrant stocks between the surveys with recall periods 2001 and 1999 (which were administered in 2002 and 2000). Both the agricultural and earthquake shocks occurred between both migrant measurements. So, a regression of the change in migrant stocks between 2002 and 2000 on the shocks from 2001 provides a test of whether or not these events induced a change in the stock of migrants in the US in 2002 relative to the stock in 2000. An analogous argument applies to changes in labor supply.

\subsection{IPUMS}

We also employ data on a sub-sample of Salvadoran migrants from the $5 \%$ microsample of the 2000 United States Census (Ruggles et al. 2004). We define a Salvadoran migrant as a US resident who resided in El Salvador five years prior to being interviewed. There are 5,251 such individuals in the 2000 US Census. Because we are interested in using these data to quantify wage differentials by gender, we further restrict the sample to working-age people, whom we define to be 20 years or older. This further reduces the sample to 3,738 . We employ variables on wages, age, years in the United States, employment status, citizenship status, and education. Wages 
were constructed by dividing the respondent's total wage income in the year by the number of hours per week that the respondent reported to work multiplied by 52 . Summary statistics are reported in Table 4.

\section{Empirical Results}

We now turn to our empirical analysis. This section is organized as follows. In the next sub-section, we investigate how labor is allocated within the household in rural El Salvador. Next, we investigate how the household's migration behavior responds to risk. After that, we investigate how intra-household labor allocation responds to risk. We conclude by investigating whether or not there are any impacts of uninsured risk on labor supply outside of the household in El Salvador.

\subsection{Intra-Household Labor Allocation}

\subsubsection{In the United States}

We now investigate male-female differentials in wages and employment status among Salvadoran migrants in the US. ${ }^{16}$ Table 4 reveals two facts. First is that the average

\footnotetext{
${ }^{16}$ There is a large literature on gender differences in wages and employment in both developing and developed countries. For an excellent overview of this literature, we refer the reader to Mammen and Paxson (2000). Some of this literature has focused on determining whether these observed
} 
US wage of Salvadoran women, including women who are not in the labor force, is $\$ 2.16$ less than the wage of a Salvadoran male. Second, a far greater share of Salvadoran women (46.39\%) report being out of the labor force than Salvadoran men $(25.02 \%)$, suggesting that this wage gap is driven largely by differences in labor force participation. ${ }^{17}$ To give the reader a more comprehensive picture of these wage gaps, we plot the cumulative density functions (CDF) of wages for men and women in Figure 1. It can be seen that the male CDF dominates the female CDF and that the largest discrepancies exist when wages are zero.

We can combine this with migration information from Table 1 to get a sense of how many members in each household are both living abroad and in the labor force. According to Table 1, the average number of female and male migrants per household is 0.19 and 0.36 , respectively. Using the labor force participation rates from the US census, we calculate that a total of $0.19 * 0.5361=0.1019$ females per household are working migrants. The corresponding number for males is $0.36 * 0.7498=0.2699$.

differentials are the consequence of productivity/skill differences across genders or discrimination. Unfortunately, understanding the role that productivity differences play in determining wage and employment disparities across genders has, to a large degree, been hampered by a dearth of data on individual productivity. One notable exception is provided by Foster and Rosenzweig (1996). who do have piece-rate data and conclude that women tend to be engaged in different activities than men because of differences in comparative advantage across genders and statistical discrimination. That they find an important role for productivity differences (albeit in a different context) lends credence to our model, which assumes that labor allocation differences between genders are due to comparative advantage.

${ }^{17}$ These discrepancies most likely reflect different migration motives among men, who generally migrate for economic reasons, and women, who generally migrate to be reunited with their families. See Donato (1994) for a discussion of these motives in the case of Mexican migration. 
These calculations suggest that there are roughly 2.6 times as many working male migrants as female migrants per household.

In Table 5, we estimate wage regressions. The explanatory variables are gender, age, experience in the US, education, and citizenship status. In the first four columns, we used OLS. In the fifth and sixth columns, we estimated a Tobit model and the censored least absolute deviations (CLAD) regression of Powell (1984). ${ }^{18}$ It can be seen that even after we adjust for a number of potentially confounding variables, men still earn more than two dollars per hour more than women in the OLS regressions. In the last two columns, which display the results of censored regressions, the gap is $\$ 4.65$ (column 5) and $\$ 3.33$ (column 6). ${ }^{19}$

We find that international migration from El Salvador is predominately male. The large male-female wage gap that we found suggests that this may be, in part, driven by economic motives. Based on our theoretical framework, we would expect that if a shock were to induce Northward migration that it should have larger effects

\footnotetext{
${ }^{18}$ We prefer the OLS results and the CLAD results to the Tobit results. One reason why we like the OLS results is that we are interested in knowing the impact of gender on average wages which includes both the extensive margin (i.e. labor force participation) and the intensive margin (i.e. wage differentials among earners). The fact that the censoring is substantially higher for women is indicative that the wages that Salvadoran women would have earned had they entered the labor force was lower than their reservation wages. A simple OLS regression conveniently summarizes this. In addition, Tobit models typically rely heavily on homoskedastic disturbances and when this fails their performance can be weak. Both OLS and CLAD are robust to failures of homoskedasticity. For additional opinions on this, we refer the reader to Deaton (1997).

${ }^{19}$ We bootstrapped the standard errors in column 6 when CLAD was employed using 100 replications.
} 
on men than on women since many households are at corner solutions with respect to female migrants. ${ }^{20}$

\subsubsection{In El Salvador}

We now turn to how the distribution of hours worked in various household activities differs across genders in El Salvador. ${ }^{21}$ The activities that we consider are field, livestock, and domestic labor, which were discussed in Section 3.1.2. We calculate CDF's for the total number of hours devoted to each of these activities by an individual during the survey year by gender. For the sake of clarity, it is important to emphasize that, in contrast to the bulk of this paper where we work with household aggregates, these figures display hours worked per year by an individual. The results of this exercise are displayed in Figures 2, 3, and 4 for field, livestock, and domestic labor, respectively. These results indicate, perhaps not surprisingly, that field labor is largely (but not entirely) men's work and that domestic labor is almost exclusively women's work. They also indicate that men are marginally more likely than women to be engaged in livestock labor.

\footnotetext{
${ }^{20}$ While these results do suggest that economic considerations play an important role in the household's allocation problem, it is also important to mention that prevailing social mores in Central America about the vulnerability of women may also mean that the costs of migration, as perceived by the household, may be substantially higher for women (Curran and Rivero-Fuentes 2003).

21 In the Salvadoran data, we focus on hours worker as opposed to wages due to the fact that in developing countries a large proportion of labor is not in the wage sector.
} 
Based on our theory, these figures have the following implications. First, given that most households were at a corner solution in which no women were engaged in either field activities in El Salvador or wage labor in the US, we would expect the agricultural shocks to have smaller effects on female migration. Second, given that Figure 4 suggests that the home is the woman's domain, we would expect that the earthquakes, which ostensibly increased the demand for home production, will be dealt with increases in female hours allocated to domestic labor.

\subsection{Migration and Risk}

We now investigate how exogenous shocks in El Salvador affect the gender composition of migrant flows. Our benchmark regression equation is similar to that in Halliday (2006) and, with some abuse of notation, is given by

$$
\Delta M_{h, t}^{j}=\alpha^{j}+\zeta_{t}^{j}+\omega_{h, t}^{\prime} \delta^{j}+R_{h}^{\prime} \rho^{j}+X_{h, t-1}^{\prime} \beta+\varepsilon_{h, t}^{j} \text { for } j \in\{M, F\}
$$

where $\Delta M_{h, t}^{j}$ is the change in the stock of male or female migrants across time periods, $\zeta_{t}^{j}$ is a year effect, $\omega_{h, t}$ is a vector of exogenous shocks such as the harvest and livestock loss dummies and the earthquake damage index, $R_{h}$ is a set of location dummies and $X_{h, t}$ is a set of demographic controls which were discussed in Table 3. 
Two sets of location dummies are employed: department dummies of which there are 14 and municipio dummies of which there are $173 .{ }^{22}$ To address the obvious concern that migration will have a contemporaneous impact on the household's demographic structure, we use lags of $X_{h, t}$. We estimate the model using an ordered logit estimator with the 2001 and 1999 waves of the BASIS panel. The advantage of the ordered logit model is that it uses ancillary parameters that enable us to handle the dependent variable in a flexible manner. To account for the possibility of correlations across observations within municipios, we cluster all standard errors by municipio. Table 6 reports our results for male migration and Table 7 reports our results for female migration.

The first column of Table 6 displays estimation results when the dependent variable is total migration (i.e. the sum of male and female migration) as a reference. We see that the agricultural shocks had a positive and significant impact on migration, whereas the earthquakes had a negative and significant impact on migration. The explanation that we give in Halliday (2006) for this result is that adverse agricultural conditions in El Salvador expanded the North-South wage gap and thereby increased the incentives for Northward migration, whereas the earthquakes increased

\footnotetext{
${ }^{22}$ In fact, there are 262 municipios in El Salvador, but only 173 of these are present in our data due to the small sample sizes in the BASIS data. In addition, for some of the regressions in this paper, some municipio dummies were dropped due to collinearity with the agricultural shock dummies.
} 
the demand for labor at home which was met by a reduction in migration. In that paper, we explored the possibility that the earthquakes stunted migration because they disrupted migration financing, but the preponderance of evidence that we uncovered did not support this alternative hypothesis.

In the second column of the table, we provide a simple identification check. First, we take the shocks from the 2001 (1999) wave of the panel and merge them into the 1999 (2001) wave. We call these "counterfactual" shocks. We then estimate the specification from the first column using these counterfactual shocks while omitting the actual shocks. The central idea of this exercise is that if households have timeinvariant characteristics that are systematically correlated with both migration and the shocks then these counterfactual shocks should pick up false treatments. ${ }^{23}$ What we see is that the $F$-tests at the bottom of the column cannot reject the null that the counterfactual shocks all have zero coefficients which mitigates some of these omitted variables concerns.

Columns three through six of Table 6 use male migration as the dependent variable. In all four columns, we see that adverse agricultural shocks had a positive and significant impact on migration. All tests of joint significance had $p$-values less than

\footnotetext{
${ }^{23}$ These omitted variable biases may arise if the shocks were non-randomly assigned to households that either had weak ties to the United States or were poorer. In both scenarios, the shocks would have been assigned to households that had unobserved characteristics that made them less likely to migrate.
} 
$10 \%$. In addition, it is important to point out that in column six we use municipio dummies and, while the agricultural shock dummies are no longer individually significant, they are still jointly significant at the $10 \%$ level. ${ }^{24}$ We must emphasize that, while the standard errors on the agricultural shocks are substantially higher, the point-estimates are broadly in-line with the others in the table. This substantially mitigates concerns of omitted variables bias. ${ }^{25}$ Interestingly and in stark contrast to the first column, we see that there is no relationship between the earthquakes and male migration.

We emphasize (and reiterate) that a few points are important to bear in mind when interpreting the results in Table 6 . The first is that, while all of the agricultural shocks are not individually significant, they are all jointly significant. The second is that, while the livestock loss dummy is never individually significant, its pointestimate is of a similar magnitude to the harvest loss dummy. The third is that given the high degree of measurement error in our data and the fact that we have between 600 and 700 households total, it is not reasonable to expect extremely high

\footnotetext{
${ }^{24}$ While this procedure does mitigate omitted variables concerns, it also eliminates a substantial amount of variation in the shocks - much of which is meaningful variation. As such it is unreasonable to expect high $t$-statistics on the agricultural shocks as this is a highly inefficient procedure. Because of this, the fact that we have such a low $p$-value on our $F$-tests is a strong testament to our claim that our agricultural shocks are probably not picking up omitted variables.

${ }^{25}$ For example, the areas in El Salvador with long histories of migration to the US are in the rural northern and eastern parts of the country which were hit hardest by the civil war. It might be reasonable to expect that these areas also have a higher prevalence of risky agricultural activities which could create a spurious relationship between the agricultural shocks and migration. For a more comprehensive discussion of some of these omitted variables concerns, see Halliday (2006).
} 
levels of significance in the table. ${ }^{26}$ Finally, while the use of the municipio dummies does increase the standard errors, it does not affect the point-estimates.

This is consistent with the critique in Deaton (1995) in which he says that, while the inclusion of fixed effects in regressions does mitigate concerns of omitted variables, it comes with the added cost of lower efficiency, particularly, in the presence of measurement error. These costs are even higher when the independent variables are serially correlated over time. This final point, we believe, suggests that the inclusion of department dummies, rather than municipio dummies, is a good compromise between addressing omitted variables while not paying too high of a cost in efficiency loss.

Turning to the results for female migration in Table 7 , we see a substantially different picture. Now the relationship between the agricultural shocks and migration is more muted than in the previous table as can seen by the lower point estimates and $F$-tests at the bottom of the table. In addition, we now see a large, negative, and statistically significant relationship between the earthquakes and migration. In fact, the point estimates for women are substantially larger than the estimate in the first column of the previous table, where the dependent variable was total migration. Finally, the earthquake effects are greatest when we include the municipio dummies,

\footnotetext{
${ }^{26}$ The 1265 households reported at the bottom of the table double counts households.
} 
which once again mitigates many omitted variables concerns.

These results are broadly consistent with the observed allocations of labor within Salvadoran households. We observed that both labor in the North and on the farm in the South are male dominated. Consistent with theory, we observed that the agricultural shocks impacted male migration and had no effects on female migration. In addition, if one believes that the earthquakes increased the demand for domestic services in the South then the large negative impacts of the earthquakes on female migration are consistent with the observation that domestic labor is female dominated.

\subsection{Intra-Household Labor Allocation and Risk}

We now turn to how stochastic shocks affect the allocation of labor within the house-

hold in El Salvador. We define $H_{h, t}^{j, s}$ to be the number of labor hours devoted to sector $s$ by all members of household $h$ of gender $j$ in year $t$ where the sectors are field, livestock and domestic activity. We then estimate a similar model to equation (3) except that we use $\Delta H_{h, t}^{j, s}$ as the dependent variable using OLS. Each regression includes a set of department dummies and (lagged) demographic controls. Our core results are reported in Table 8.

First, consider the coefficient estimates on the earthquake damage index. In 
the last column of the table, we see that households that were hit hard by the earthquakes also experienced a dramatic increase in the number of hours devoted to domestic labor by women. The proper interpretation of the point estimate is that a $1 \%$ increase in earthquake damage is associated with an increase of 1.54 hours devoted to domestic labor by women. This implies that a household that was hit three times harder by the earthquakes than another experienced a 462 hour increase in hours devoted to domestic work by women during the year, on average! In contrast, in column five, we see that the earthquakes had no effect on male hours devoted to domestic activities. Finally, we note that the estimate on earthquake damage in column four, where the dependent variable is the change in livestock hours worked by women, is negative and moderately significant suggesting that the earthquakes may have induced a substitution away from livestock production toward home production.

Next, consider the effects of the two agricultural shocks on hours. We see that harvest losses had large, positive and significant effects on field hours for men. We also see that livestock losses had similar effects on livestock hours for both men and women. However, livestock losses had no effects on field hours, nor did harvest losses have any effects on livestock hours for either men or women.

Towards the bottom of the table, we report the results of falsification tests that 
are similar to those in column 2 of Table 6 . We observe that the $p$-values on the $F$-tests are all quite high and always greater than $10 \%$. This mitigates concerns that the shock variables are picking up omitted variables.

There is an interesting concordance between these results and the analysis of hours worked by gender discussed above. We established that, compared to women, men are more likely to work in the fields, equally as likely to work with livestock, and less likely to do domestic work. The effects of the shocks on labor in the field, livestock, and domestic sectors follow a similar pattern in the sense that the harvest shocks had larger effects on men than women, the livestock shocks had similar effects, and the earthquakes had smaller effects. This empirical result is very much consistent with the discussion of comparative advantage in the theoretical section of the paper.

In addition, the results in the table suggest that a subsistence constraint may be binding. Indeed, we would expect that the harvest and livestock shocks which presumably lowered marginal productivity in agricultural activities in El Salvador would tend to have induced a substitution away from (not towards) agricultural activities. ${ }^{27}$ Moreover, we also found that these same shocks induced Northward migration.

\footnotetext{
${ }^{27}$ A similar result was found by Frankenberg, Smith, and Thomas (2003), who show that there was a tendency for the labor supply to increase in the aftermath of the Indonesian financial crisis in the late 1990s despite the fact that it caused a $40 \%$ reduction in real wages in the formal sector.
} 
Do these findings pose a paradox? Our theory suggests not. Essentially, the household increases farm hours to keep their heads above water, while at the same time sending members abroad. The migration effects serve two purposes. One is also to help the family subsist. The second is a standard substitution effect in which the returns to labor on the farm are low and so the family substitutes towards better remunerated activities.

We conclude this sub-section with two robustness checks. In the first, we estimate models similar to those in Table 8 except that now we employ the number of hours devoted to a particular labor activity per adult male or female (i.e. total hours worked by the household divided by the number of adult men or women) as the dependent variable. ${ }^{28}$ These results are reported in Table 9. Overall, our conclusions are unaffected, although we do see that the coefficient on livestock loss is diminished in column 3. In the second robustness check, we re-estimate the regressions in Table 8, but with municipio dummies in lieu of department dummies. These results are reported in Table 10. Once again, our conclusions are unaffected and, if anything, are stronger.

\footnotetext{
${ }^{28}$ We define an adult to be anyone 16 years of age or older.
} 


\subsection{Outside Labor Supply and Risk}

We conclude this section by estimating the impact of uninsured risk on the household's labor supplied outside of the household in El Salvador. To do this, we estimate a model similar to equation (3) except that now the dependent variable is the change in the number of household members (of a given gender) who reported working in a given sector across successive survey years. As with the migration variable, here we also use an ordered logit model. The results are reported in Table 11 for men and Table 12 for women. Overall, we do not see any effects of exogenous shocks on labor supplied outside of the household. The entire impact of uninsured risk appears to be absorbed within the household and by the US labor market.

\section{Conclusions}

Using panel data from El Salvador, we investigated how the intra-household allocation of labor responds to stochastic shocks within the context of a model of a farm household in that country. We showed that adverse shocks in the agricultural sector were met by increases in the number of male migrants living in the US and by increases in male hours devoted to agricultural activities on the household's farm. This finding is consistent with the presence of a binding subsistence constraint. In 
contrast, damage sustained by households due to the 2001 earthquakes had a large negative effect on female migration, but had absolutely no effect on male migration. We also showed that the earthquakes were met by a dramatic increase in the number of hours that women devoted to domestic labor, but had no impact on male domestic hours. This is consistent with the finding in our data that over $90 \%$ of all households do not allocate any males to domestic activities. Thus it appears that it was the women who picked up the pieces left by the disaster. Overall, our findings suggest that household responses to adverse shocks are consistent with a simple framework in which household members are allocated to different sectors according to their comparative advantage. Finally, we showed that the local labor market in El Salvador does not help households to mitigate the effects of adverse shocks. Our findings are consistent with a model in which rural Salvadoran households are behaving rationally, but at a subsistence level.

\section{References}

[1] Barzel, Y. and R.J. McDonald. 1973. "Assets, Subsistence and the Supply Curve." American Economic Review. 63(4): 621-633.

[2] Benjamin, D. 1992. "Household Composition, Labor Markets and Labor De- 
mand: Testing for Separation in Agricultural Household Models." Econometrica. 60(2): 287-322.

[3] Besley, T. 1995. "Savings, Credit and Insurance." In Handbook of Development Economics. vol. 3A, eds. J. Behrman and T.N. Srinivasan. Amsterdam: North Holland.

[4] Browning, M., Bourguignon, F., Chiappori, P.A. and V. Lechene. 1994. "Income and Outcomes: A Structural Model of Intra-Household Allocation." Journal of Political Economy. 102(6): 1067-1096.

[5] Curran, S.R. and E. Rivero-Fuentes. 2003. "Engendering Migrant Networks: The Case of Mexican Migration.” Demography. 40(2): 289 - 307.

[6] Deaton, A. 1995. "Data and Econometric Tools for Development Analysis." In Handbook of Development Economics. vol. 3A, eds. J. Behrman and T.N. Srinivasan. Amsterdam: North Holland.

[7] Deaton, A. 1997. The Analysis of Household Surveys: A Microeconometric Approach to Development Policy. Johns Hopkins Press: Baltimore, MD.

[8] Donato, K. 1994. "Current Trends and Patterns of Female Migration: Evidence from Mexico." International Migration Review. 27: 748-768. 
[9] Foster, A. and M. Rosenzweig. 1996. "Comparative Advantage, Information and the Allocation of Workers to Tasks: Evidence from an Agricultural Labor Market." Review of Economic Studies. 63(3): 347-374.

[10] Frankenberg, E., Smith, J. and D. Thomas. 2003. "Economic Shocks, Wealth and Welfare." Journal of Human Resources. 38(2): 280-321.

[11] Halliday, T. 2006. "Migration, Risk and Liquidity Constraints in El Salvador," Economic Development and Cultural Change. 54(4): 893 - 925.

[12] Kochar, A. 1999. "Smoothing Consumption by Smoothing Income: Hours of Work Responses to Idiosyncratic Agricultural Shocks in Rural India." Review of Economics and Statistics. 81(1): 50-61.

[13] Mammen, K. and C. Paxson. 2000. "Women's Work and Economic Development." Journal of Economic Perspectives. 14(4): 141-164.

[14] Munshi, K. 2003. "Networks in the Modern Economy: Mexican Migrants in the US Labor Market." Quarterly Journal of Economics. 118(2): 549-599.

[15] Nicolás, N.A. and R.S. Olson. 2001. "SUMA and the 2001 El Salvador Earthquakes: An Independent External Evaluation." report submitted to the PanAmerican Health Organization, Washington, DC, July 1, 2001. 
[16] Paulson, A.L. 2000. "Insurance and Migration: Evidence from Thailand." unpublished mimeo, University of Chicago.

[17] Paxson, CH. 1990. "Borrowing Constraints and Portfolio Choice." Quarterly Journal of Economics. 105(2): 535-543.

[18] Paxson, C.H. 1992. "Using Weather Variability to Estimate the Response of Savings to Transitory Income in Thailand." American Economic Review. 82(1): $15-33$.

[19] PNUD (Programa de las Naciones Unidas de Desarollo). 2001. Informe sobre desarollo humano: El Salvador New York: Programa de las Naciones Unidas de Desarollo (United Nations Development Programme).

[20] Powell, J.L. 1984. "Least Absolute Deviations Estimation of the Censored Regression Model." Journal of Econometrics. 25(3): 303-325.

[21] Rosenzweig, M.R. and O. Stark. 1989. "Consumption Smoothing, Migration, and Marriage: Evidence from Rural India." Journal of Political Economy. 97(4): 905-926.

[22] Rosenzweig, M.R. and K.L. Wolpin. 1993. "Credit Market Constraints, Consumption Smoothing and the Accumulation of Durable Production Assets in 
Low-Income Countries: Investment in Bullocks in India." Journal of Political Economy. 101(2): 223-244.

[23] Ruggles, S., M. Sobek, T. Alexander, C.A. Fitch, R. Goeken, P.K. Hall, M. King, and C. Ronnander. Integrated Public Use Microdata Series: Version 3.0 [Machine-readable database]. Minneapolis, MN: Minnesota Population Center [producer and distributor], 2004.

[24] Scott, J.C. 1976. The Moral Economy of the Peasant. Yale University Press: New Haven, CT.

[25] Tawney, R.H. 1966. Land and Labor in China. Beacon Press: Boston, MA.

[26] Townsend, R.M. 1994. "Risk and Insurance in Village India." Economtrica. 62(3): 539-591.

[27] Udry, C. 1994a. "Risk and Insurance in a Rural Credit Market: An Empirical Investigation in Northern Nigeria." Review of Economic Studies. 61(3): 495-526.

[28] Udry, C. 1994b. "Risk and Savings in Northern Nigeria." American Economic Review. 85(5): 1287-1300.

[29] Yang, D. and H. Choi. 2007. "Are Remittances Insurance? Evidence from Rainfall Shocks in the Philippines." World Bank Economic Review. 21(2): 219-248. 
Table 1: Summary Statistics from BASIS: Migration, Hours Worked in Household Activities, and Economic Shocks

\begin{tabular}{|c|c|c|}
\hline & Definition & $\begin{array}{c}\text { Mean } \\
\text { (Standard Deviation) }\end{array}$ \\
\hline Migrants $^{1}$ & $\begin{array}{l}\text { Number of household members residing in the } \\
\text { United States }\end{array}$ & $\begin{array}{c}0.55 \\
(1.23)\end{array}$ \\
\hline - Women & & $\begin{array}{c}0.19 \\
(0.62)\end{array}$ \\
\hline - Men & & $\begin{array}{c}0.36 \\
(0.83)\end{array}$ \\
\hline Field Hours ${ }^{1}$ & $\begin{array}{l}\text { Total number of hours in the year that household } \\
\text { members devoted to field labor }\end{array}$ & $\begin{array}{c}1065.33 \\
(1584.32)\end{array}$ \\
\hline - Women & & $\begin{array}{c}70.21 \\
(341.17)\end{array}$ \\
\hline - Men & & $\begin{array}{c}995.12 \\
(1512.21)\end{array}$ \\
\hline Livestock Hours $^{1}$ & $\begin{array}{l}\text { Total number of hours in the year that household } \\
\text { members devoted to caring for livestock }\end{array}$ & $\begin{array}{c}474.17 \\
(928.88)\end{array}$ \\
\hline - Women & & $\begin{array}{c}234.33 \\
(489.25)\end{array}$ \\
\hline - Men & & $\begin{array}{c}239.84 \\
(723.92)\end{array}$ \\
\hline Domestic Hours $^{1}$ & $\begin{array}{l}\text { Total number of hours in the year that household } \\
\text { members devoted to domestic labor }\end{array}$ & $\begin{array}{c}4533.91 \\
(3439.47)\end{array}$ \\
\hline - Women & & $\begin{array}{c}4311.83 \\
(3108.16)\end{array}$ \\
\hline - Men & & $\begin{array}{c}222.09 \\
(1024.85)\end{array}$ \\
\hline Harvest Loss ${ }^{2}$ & $\begin{array}{l}\text { Dummy indicating income loss due to harvest } \\
\text { loss }\end{array}$ & $\begin{array}{c}0.19 \\
(0.39)\end{array}$ \\
\hline Livestock Loss ${ }^{2}$ & $\begin{array}{l}\text { Dummy indicating income loss due to livestock } \\
\text { loss }\end{array}$ & $\begin{array}{c}0.11 \\
(0.31)\end{array}$ \\
\hline Quakedamage $^{3}$ & $\begin{array}{l}\text { Cost of all household damage due to the } 2001 \\
\text { earthquakes (in } 1992 \$ \text {, in logs) }\end{array}$ & $\begin{array}{c}4.64 \\
(3.80)\end{array}$ \\
\hline
\end{tabular}

${ }^{1}$ Data are from 1997, 1999 and 2001. Sample size is 2008.

${ }^{2}$ Data are from 1999 and 2001. Sample size is 1365.

${ }^{3}$ Data are from 2001. Sample size is 689 . 
Table 2: Summary Statistics from BASIS: Outside Labor Supply

\begin{tabular}{|c|c|c|}
\hline & Definition & $\begin{array}{c}\text { Mean } \\
\text { (Standard Deviation) } \\
\end{array}$ \\
\hline Outside Labor & $\begin{array}{l}\text { Number of family members that worked } \\
\text { outside of the household in any sector }\end{array}$ & $\begin{array}{c}1.62 \\
(1.46)\end{array}$ \\
\hline - Women & & $\begin{array}{c}0.48 \\
(0.81)\end{array}$ \\
\hline - Men & & $\begin{array}{l}1.15 \\
(1.06)\end{array}$ \\
\hline Outside - Agriculture ${ }^{1}$ & $\begin{array}{l}\text { Number of family members that worked outside } \\
\text { of the household in the agricultural sector }\end{array}$ & $\begin{array}{c}0.93 \\
(1.33)\end{array}$ \\
\hline - Women & & $\begin{array}{c}0.21 \\
(0.61)\end{array}$ \\
\hline - Men & & $\begin{array}{c}0.72 \\
(1.02)\end{array}$ \\
\hline Outside - Industry $^{1}$ & $\begin{array}{l}\text { Number of family members that worked outside } \\
\text { of the household in the industrial sector }\end{array}$ & $\begin{array}{c}0.27 \\
(0.57)\end{array}$ \\
\hline - Women & & $\begin{array}{c}0.01 \\
(0.12)\end{array}$ \\
\hline - Men & & $\begin{array}{c}0.25 \\
(0.55)\end{array}$ \\
\hline Outside - Commercial & $\begin{array}{l}\text { Number of family members that worked outside } \\
\text { of the household in the commercial sector }\end{array}$ & $\begin{array}{c}0.14 \\
(0.48)\end{array}$ \\
\hline - Women & & $\begin{array}{c}0.09 \\
(0.37)\end{array}$ \\
\hline - Men & & $\begin{array}{c}0.06 \\
(0.25)\end{array}$ \\
\hline Outside - Services & $\begin{array}{l}\text { Number of family members that worked outside } \\
\text { of the household in the service sector }\end{array}$ & $\begin{array}{c}0.36 \\
(0.66)\end{array}$ \\
\hline - Women & & $\begin{array}{c}0.16 \\
(0.43)\end{array}$ \\
\hline - Men & & $\begin{array}{c}0.20 \\
(0.48)\end{array}$ \\
\hline Outside - Textiles & $\begin{array}{l}\text { Number of family members that worked outside } \\
\text { of the household in the textile sector }\end{array}$ & $\begin{array}{c}0.07 \\
(0.31)\end{array}$ \\
\hline - Women & & $\begin{array}{c}0.05 \\
(0.26)\end{array}$ \\
\hline - Men & & $\begin{array}{c}0.02 \\
(0.15)\end{array}$ \\
\hline
\end{tabular}

+ All data are from 1997, 1999 and 2001. Sample size is 2008. 
Table 3: Summary Statistics from BASIS: Demographic Variables

\begin{tabular}{lcc}
\hline Age Bracket & Men & Women \\
\hline$<1$ & 0.04 & 0.04 \\
& $(0.21)$ & $(0.19)$ \\
$1-15$ & 1.18 & 1.20 \\
& $(1.29)$ & $(1.26)$ \\
$16-20$ & 0.38 & 0.37 \\
& $(0.65)$ & $(0.63)$ \\
$21-45$ & 0.75 & 0.89 \\
& $(0.76)$ & $(0.71)$ \\
$>45$ & 0.62 & 0.53 \\
& $(0.55)$ & $(0.55)$ \\
\hline
\end{tabular}

${ }^{*}$ Standard deviations are reported in parentheses. Data are from the 1997, 1999 and 2001 waves of the survey. 
Table 4: Summary Statistics from IPUMS

\begin{tabular}{lcc}
\hline & Men & Women \\
\hline Wage & 5.44 & 3.28 \\
& $(6.45)$ & $(8.79)$ \\
Age & 30.70 & 34.26 \\
& $(12.29)$ & $(15.02)$ \\
Years in the US & 3.99 & 4.21 \\
Employment distribution & $(5.65)$ & $(6.29)$ \\
- Employed & & \\
- Unemployed & $69.39 \%$ & $45.66 \%$ \\
- Not in labor force & $5.58 \%$ & $7.95 \%$ \\
Citizenship Status & $25.02 \%$ & $46.39 \%$ \\
- Born abroad of American Citizens & $0.20 \%$ & \\
- Naturalized Citizen & $4.98 \%$ & $0.44 \%$ \\
- Not a citizen & $94.82 \%$ & $5.00 \%$ \\
Education & & $94.56 \%$ \\
- None & $13.76 \%$ & $14.46 \%$ \\
- 1 to 4 Years & $8.04 \%$ & $7.95 \%$ \\
- 5 to 8 Years & $25.70 \%$ & $24.04 \%$ \\
- 9 Years & $11.36 \%$ & $9.58 \%$ \\
- 10 Years & $2.89 \%$ & $2.83 \%$ \\
- 11 Years & $3.08 \%$ & $3.19 \%$ \\
- 12 Years & $22.95 \%$ & $22.47 \%$ \\
- 1 to 3 Years of College & $7.75 \%$ & $10.06 \%$ \\
- 4 or more Years of College & $4.48 \%$ & $5.42 \%$ \\
\hline
\end{tabular}

${ }^{*}$ The data in this table come from a sub-sample of Salvadorans in the US who were residing in El Salvador in 1995 who were at least 20 years old. Standard deviation in parentheses. Wages are in $1999 \$$. 
Table 5: US Wage Regressions

\begin{tabular}{|c|c|c|c|c|c|c|}
\hline & $(1)$ & $(2)$ & $(3)$ & $(4)$ & $(5)$ & $(6)$ \\
\hline Male Dum & $\begin{array}{c}2.09 \\
(8.40)\end{array}$ & $\begin{array}{c}2.07 \\
(8.35)\end{array}$ & $\begin{array}{c}2.11 \\
(8.54)\end{array}$ & $\begin{array}{c}2.09 \\
(8.45)\end{array}$ & $\begin{array}{c}4.65 \\
(12.19)\end{array}$ & $\begin{array}{c}3.33 \\
(9.00)\end{array}$ \\
\hline Age & $\begin{array}{c}0.28 \\
(6.16)\end{array}$ & $\begin{array}{c}0.22 \\
(4.83)\end{array}$ & $\begin{array}{c}0.20 \\
(4.21)\end{array}$ & $\begin{array}{c}0.20 \\
(4.21)\end{array}$ & $\begin{array}{c}0.55 \\
(6.70)\end{array}$ & $\begin{array}{l}0.35 \\
(3.5)\end{array}$ \\
\hline $\mathrm{Age}^{2}$ & $\begin{array}{l}-0.003 \\
(-6.82)\end{array}$ & $\begin{array}{l}-0.003 \\
(-5.69)\end{array}$ & $\begin{array}{l}-0.003 \\
(-4.99)\end{array}$ & $\begin{array}{l}-0.003 \\
(-5.06)\end{array}$ & $\begin{array}{l}-0.008 \\
(-8.22)\end{array}$ & $\begin{array}{c}-0.005 \\
(3.33)\end{array}$ \\
\hline US Exp & - & $\begin{array}{c}0.30 \\
(7.22)\end{array}$ & $\begin{array}{c}0.31 \\
(7.40)\end{array}$ & $\begin{array}{c}0.33 \\
(7.60)\end{array}$ & $\begin{array}{c}0.52 \\
(7.42)\end{array}$ & $\begin{array}{c}0.82 \\
(4.82)\end{array}$ \\
\hline US Exp ${ }^{2}$ & - & $\begin{array}{l}-0.005 \\
(-4.94)\end{array}$ & $\begin{array}{l}-0.006 \\
(-5.26)\end{array}$ & $\begin{array}{l}-0.006 \\
(-5.67)\end{array}$ & $\begin{array}{l}-0.010 \\
(-4.65)\end{array}$ & $\begin{array}{l}-0.036 \\
(-3.00)\end{array}$ \\
\hline Ed. Dum? & No & No & Yes & Yes & Yes & Yes \\
\hline Citizen. Dum? & No & No & No & Yes & Yes & Yes \\
\hline Estimator & OLS & OLS & OLS & OLS & Tobit & CLAD \\
\hline$R^{2}$ & 0.0327 & 0.0469 & 0.0548 & 0.0571 & 0.0216 & 0.0637 \\
\hline$N$ & 3738 & 3738 & 3738 & 3738 & 3738 & 3738 \\
\hline
\end{tabular}

${ }^{*}$ These regressions use the same data as Table 3. $t$-ratios are in parentheses. 
Table 6: Migratory Responses to Adverse Shocks: Male Migration

\begin{tabular}{|c|c|c|c|c|c|c|}
\hline & $(1)^{3}$ & $(2)^{3,4}$ & $(3)$ & $(4)$ & $(5)$ & (6) \\
\hline Harvest Loss & $\begin{array}{c}0.31 \\
(1.89)\end{array}$ & $\begin{array}{c}-0.23 \\
(-1.33)\end{array}$ & $\begin{array}{c}0.40 \\
(2.23)\end{array}$ & $\begin{array}{c}0.40 \\
(2.18)\end{array}$ & $\begin{array}{c}0.36 \\
(1.97)\end{array}$ & $\begin{array}{c}0.34 \\
(1.49)\end{array}$ \\
\hline Livestock Loss & $\begin{array}{c}0.36 \\
(1.84)\end{array}$ & $\begin{array}{l}-0.00 \\
(-0.02)\end{array}$ & $\begin{array}{c}0.29 \\
(1.17)\end{array}$ & $\begin{array}{c}0.28 \\
(1.13)\end{array}$ & $\begin{array}{c}0.31 \\
(1.23)\end{array}$ & $\begin{array}{c}0.40 \\
(1.50)\end{array}$ \\
\hline Earthquake Damage & $\begin{array}{l}-0.05 \\
(-2.15)\end{array}$ & $\begin{array}{c}0.00 \\
(0.02)\end{array}$ & $\begin{array}{l}-0.01 \\
(-0.60)\end{array}$ & $\begin{array}{l}-0.01 \\
(-0.61)\end{array}$ & $\begin{array}{l}-0.00 \\
(-0.09)\end{array}$ & $\begin{array}{c}0.00 \\
(0.16)\end{array}$ \\
\hline 2001 Dummy & $\begin{array}{l}-0.28 \\
(-1.55)\end{array}$ & $\begin{array}{l}-0.40 \\
(-2.05)\end{array}$ & $\begin{array}{l}-0.40 \\
(-2.22)\end{array}$ & $\begin{array}{l}-0.38 \\
(-2.09)\end{array}$ & $\begin{array}{l}-0.43 \\
(-2.27)\end{array}$ & $\begin{array}{l}-0.49 \\
(-2.32)\end{array}$ \\
\hline Demographic Variables ${ }^{1}$ & No & No & No & Yes & Yes & Yes \\
\hline Municipio Dummies & No & No & No & No & No & Yes \\
\hline Department Dummies & No & No & No & No & Yes & No \\
\hline Decomposition? & All & All & Male & Male & Male & Male \\
\hline$F$-test on $\mathrm{Ag}$ Shocks ${ }^{2}$ & $\begin{array}{c}8.32 \\
{[0.016]}\end{array}$ & $\begin{array}{c}1.78 \\
{[0.411]}\end{array}$ & $\begin{array}{c}7.59 \\
{[0.023]}\end{array}$ & $\begin{array}{c}7.29 \\
{[0.026]}\end{array}$ & $\begin{array}{c}7.09 \\
{[0.029]}\end{array}$ & $\begin{array}{c}5.60 \\
{[0.061]}\end{array}$ \\
\hline$F$-test on All Shocks ${ }^{2}$ & $\begin{array}{c}12.18 \\
{[0.007]}\end{array}$ & $\begin{array}{c}1.79 \\
{[0.616]}\end{array}$ & $\begin{array}{c}7.83 \\
{[0.050]}\end{array}$ & $\begin{array}{c}7.54 \\
{[0.057]}\end{array}$ & $\begin{array}{c}7.09 \\
{[0.069]}\end{array}$ & $\begin{array}{c}5.73 \\
{[0.126]}\end{array}$ \\
\hline $\begin{array}{l}\text { Pseudo } R^{2} \\
\text { Households }\end{array}$ & $\begin{array}{c}0.0078 \\
1265\end{array}$ & $\begin{array}{c}0.0039 \\
1244\end{array}$ & $\begin{array}{c}0.0070 \\
1265\end{array}$ & $\begin{array}{c}0.0080 \\
1265\end{array}$ & $\begin{array}{c}0.0237 \\
1265\end{array}$ & $\begin{array}{c}0.0601 \\
1265\end{array}$ \\
\hline
\end{tabular}

${ }^{*}$ This table contains estimates from an ordered logit model where the dependent variable is male migration. All standard errors allow for clustering within municipios. $t$-statistics reported in parentheses.

${ }^{1}$ The demographic controls that were used are indicators for the number of household members at home within certain age and gender brackets reported in Table 2. ${ }^{2} p$-values are reported below each $F$-statistic.

${ }^{3}$ In this column, the dependent variable is the sum of male and female migration.

${ }^{4}$ In this column, we employed the "counterfactual" shocks described in Section 4. 
Table 7: Migratory Responses to Adverse Shocks: Female Migration

\begin{tabular}{|c|c|c|c|c|}
\hline & (1) & (2) & (3) & (4) \\
\hline Harvest Loss & $\begin{array}{c}0.29 \\
(1.64)\end{array}$ & $\begin{array}{c}0.29 \\
(1.63)\end{array}$ & $\begin{array}{c}0.26 \\
(1.43)\end{array}$ & $\begin{array}{c}0.22 \\
(0.99)\end{array}$ \\
\hline Livestock Loss & $\begin{array}{c}0.20 \\
(0.92)\end{array}$ & $\begin{array}{c}0.20 \\
(0.93)\end{array}$ & $\begin{array}{c}0.19 \\
(0.83)\end{array}$ & $\begin{array}{c}0.27 \\
(1.03)\end{array}$ \\
\hline Earthquake Damage & $\begin{array}{c}-0.07 \\
(-2.17)\end{array}$ & $\begin{array}{c}-0.07 \\
(-2.13)\end{array}$ & $\begin{array}{c}-0.07 \\
(-2.02)\end{array}$ & $\begin{array}{c}-0.09 \\
(-2.17)\end{array}$ \\
\hline 2001 Dummy & $\begin{array}{c}-0.09 \\
(-0.36)\end{array}$ & $\begin{array}{c}-0.11 \\
(-0.41)\end{array}$ & $\begin{array}{c}-0.11 \\
(-0.40)\end{array}$ & $\begin{array}{c}-0.02 \\
(-0.08)\end{array}$ \\
\hline Demographic Variables $^{1}$ & No & Yes & Yes & Yes \\
\hline Municipio Dummies & No & No & No & Yes \\
\hline Department Dummies & No & No & Yes & No \\
\hline$F$-test on $\mathrm{Ag}$ Shocks ${ }^{2}$ & $\begin{array}{c}3.87 \\
{[0.145]}\end{array}$ & $\begin{array}{c}3.94 \\
{[0.140]}\end{array}$ & $\begin{array}{c}2.94 \\
{[0.230]}\end{array}$ & $\begin{array}{c}1.88 \\
{[0.390]}\end{array}$ \\
\hline$F$-test on All Shocks ${ }^{2}$ & $\begin{array}{c}9.12 \\
{[0.028]}\end{array}$ & $\begin{array}{c}8.91 \\
{[0.030]}\end{array}$ & $\begin{array}{c}7.26 \\
{[0.064]}\end{array}$ & $\begin{array}{c}7.14 \\
{[0.068]}\end{array}$ \\
\hline Pseudo $R^{2}$ & 0.0082 & 0.0130 & 0.0170 & 0.0769 \\
\hline Households & 1265 & 1265 & 1265 & 1265 \\
\hline
\end{tabular}

${ }^{*}$ This table contains estimates from an ordered logit model where the dependent variable is female migration. All standard errors allow for clustering within municipios. $t$-statistics reported in parentheses.

${ }^{1}$ The demographic controls that were used are indicators for the number of household members at home within certain age and gender brackets. Details are in Section 2.3. ${ }^{2} p$-values are reported below each $F$-statistic. 
Table 8: Adverse Shocks and Hours Worked

\begin{tabular}{l|cccccc}
\multicolumn{2}{c}{} & \multicolumn{2}{c}{$\Delta$ Field Hours } & \multicolumn{2}{c}{$\Delta$ Livestock Hours } & \multicolumn{2}{c}{$\Delta$ Domestic Hours } \\
& Men & Women & Men & Women & Men & Women \\
& $(1)$ & $(2)$ & $(3)$ & $(4)$ & $(5)$ & $(6)$ \\
\hline \hline \multirow{2}{*}{ Harvest Loss } & 336.53 & 53.66 & 29.30 & -44.63 & -94.78 & -71.01 \\
& $(2.69)$ & $(1.22)$ & $(0.40)$ & $(-0.86)$ & $(-1.04)$ & $(-0.25)$ \\
Livestock Loss & 63.16 & 28.55 & 155.36 & 134.41 & -59.90 & 612.01 \\
& $(0.41)$ & $(0.47)$ & $(1.96)$ & $(2.36)$ & $(-0.66)$ & $(1.90)$ \\
Earthquake Damage & 13.40 & 3.27 & 9.37 & -11.73 & 8.38 & 153.80 \\
& $(0.90)$ & $(0.62)$ & $(1.11)$ & $(-1.82)$ & $(0.33)$ & $(3.86)$ \\
2001 Dummy & -8.07 & -5.43 & -283.07 & -98.54 & -435.66 & -179.53 \\
$R^{2}$ & $(-0.07)$ & $(-0.16)$ & $(-4.39)$ & $(-2.38)$ & $(-1.67)$ & $(-0.48)$ \\
& 0.0384 & 0.0207 & 0.0381 & 0.0405 & 0.0203 & 0.0644 \\
\hline \hline \multirow{2}{*}{ Count-Fac Ag Shocks ${ }^{1}$} & 2.15 & 0.72 & 0.35 & 1.05 & 0.92 & 0.10 \\
& {$[0.120]$} & {$[0.491]$} & {$[0.707]$} & {$[0.353]$} & {$[0.402]$} & {$[0.905]$} \\
Count-Fac All Shocks ${ }^{1}$ & 1.44 & 0.86 & 0.49 & 1.77 & 0.61 & 1.89 \\
& {$[0.233]$} & {$[0.461]$} & {$[0.689]$} & {$[0.154]$} & {$[0.607]$} & {$[0.133]$} \\
\hline \hline \multicolumn{1}{l}{ Households } & 1265 & 1265 & 1265 & 1265 & 1265 & 1265
\end{tabular}

${ }^{*}$ This table contains OLS estimates where the dependent variable is the change in hours worked in a particular sector broken down by gender. All regressions contain lagged demographic controls and department dummies. All standard errors allow for clustering within municipios.

$t$-statistics reported in parentheses.

${ }^{1}$ Reports the $F$-test that the counter-factual shock coefficient estimates were zero. These results were obtained from separate regressions $(\mathrm{N}=1244)$ in which the specifications were identical to those in this table except that the actual shocks were replaced with the counter-factual shocks. $p$-value is in brackets. 
Table 9: Robustness Check: Adverse Shocks and Hours Worked - per Capita

\begin{tabular}{l|cccccc}
\multicolumn{1}{c}{} & \multicolumn{2}{c}{$\Delta$ Field Hours } & \multicolumn{2}{c}{$\Delta$ Livestock Hours } & \multicolumn{2}{c}{$\Delta$ Domestic Hours } \\
& Men & Women & Men & Women & Men & Women \\
& $(1)$ & $(2)$ & $(3)$ & $(4)$ & $(5)$ & $(6)$ \\
\hline \hline \multirow{2}{*}{ Harvest Loss } & 134.43 & 39.99 & 53.23 & -47.50 & -52.40 & 106.98 \\
& $(2.07)$ & $(1.58)$ & $(1.19)$ & $(-1.15)$ & $(-0.78)$ & $(0.64)$ \\
Livestock Loss & 61.60 & 10.09 & 69.10 & 80.74 & -19.80 & 312.64 \\
& $(0.76)$ & $(0.37)$ & $(1.32)$ & $(1.98)$ & $(-0.35)$ & $(1.64)$ \\
Earthquake Damage & 1.31 & 1.15 & 5.57 & -10.15 & -2.88 & 49.42 \\
& $(0.19)$ & $(0.41)$ & $(1.07)$ & $(-2.17)$ & $(-0.25)$ & $(2.20)$ \\
2001 Dummy & 12.24 & -0.37 & -180.24 & -65.37 & -218.45 & 81.87 \\
$R^{2}$ & $(0.23)$ & $(-0.02)$ & $(-4.09)$ & $(-2.13)$ & $(-2.12)$ & $(0.38)$ \\
Households & 0.0247 & 0.0129 & 0.0403 & 0.0370 & 0.0292 & 0.0429 \\
& 1265 & 1265 & 1265 & 1265 & 1265 & 1265
\end{tabular}

${ }^{*}$ This table contains OLS estimates where the dependent variable is the change in hours worked per adult male or female in a particular sector broken down by gender. All regressions contain lagged demographic controls and department dummies. All standard errors allow for clustering within municipios. $t$-statistics reported in parentheses. 
Table 10: Robustness Check: Adverse Shocks and Hours Worked - Municipio FE

\begin{tabular}{l|cccccc}
\multicolumn{1}{c}{} & \multicolumn{2}{c}{$\Delta$ Field Hours } & \multicolumn{2}{c}{$\Delta$ Livestock Hours } & \multicolumn{2}{c}{$\Delta$ Domestic Hours } \\
& Men & Women & Men & Women & Men & Women \\
& $(1)$ & $(2)$ & $(3)$ & $(4)$ & $(5)$ & $(6)$ \\
\hline \hline \multirow{2}{*}{ Harvest Loss } & 441.98 & 65.88 & 40.95 & -56.27 & -111.36 & -37.01 \\
& $(2.85)$ & $(1.29)$ & $(0.45)$ & $(-0.92)$ & $(-0.97)$ & $(-0.11)$ \\
Livestock Loss & 105.39 & 22.25 & 185.22 & 141.59 & -84.42 & 456.41 \\
& $(0.58)$ & $(0.32)$ & $(1.92)$ & $(2.04)$ & $(-0.77)$ & $(1.19)$ \\
Earthquake Damage & 5.63 & 3.20 & 11.04 & -12.42 & 11.20 & 174.85 \\
& $(0.31)$ & $(0.50)$ & $(1.09)$ & $(-1.59)$ & $(0.34)$ & $(3.42)$ \\
2001 Dummy & 18.87 & -3.21 & -300.65 & -93.10 & -448.14 & -275.61 \\
$R^{2}$ & $(0.15)$ & $(-0.08)$ & $(-4.17)$ & $(-1.97)$ & $(-1.47)$ & $(-0.65)$ \\
Households & 0.1029 & 0.1091 & 0.1398 & 0.0925 & 0.0348 & 0.1344 \\
& 1265 & 1265 & 1265 & 1265 & 1265 & 1265
\end{tabular}

${ }^{*}$ This table contains OLS estimates where the dependent variable is the change in hours worked in a sector broken down by gender. All regressions contain lagged demographic controls and municipio dummies. All standard errors allow for clustering within municipios.

$t$-statistics reported in parentheses. 
Table 11: Adverse Shocks and Hours Worked Outside the HH - Men (1) $(2)$ (3) (4) (5)

\begin{tabular}{l|ccccc}
\hline \hline \multirow{2}{*}{ Harvest Loss } & -0.07 & 0.13 & 0.20 & -0.08 & 0.43 \\
& $(-0.38)$ & $(0.75)$ & $(0.70)$ & $(-0.52)$ & $(0.99)$ \\
Livestock Loss & -0.02 & 0.03 & -0.19 & 0.14 & -0.54 \\
& $(-0.10)$ & $(0.12)$ & $(-0.67)$ & $(0.55)$ & $(-0.97)$ \\
Earthquake Damage & -0.01 & 0.02 & -0.02 & 0.04 & 0.02 \\
& $(-0.36)$ & $(0.87)$ & $(-0.38)$ & $(1.52)$ & $(0.23)$ \\
2001 Dummy & 0.07 & 0.29 & 0.16 & -0.25 & 0.20 \\
Pseudo $R^{2}$ & $(0.49)$ & $(1.74)$ & $(0.50)$ & $(-1.20)$ & $(0.33)$ \\
Sector & 0.0135 & 0.0169 & 0.0140 & 0.0095 & 0.0745 \\
Households & $\mathrm{Ag}$ & Ind & Com & Serv & Tex \\
& 1265 & 1265 & 1265 & 1265 & 1265
\end{tabular}

${ }^{*}$ This table contains ordered logit estimates where the dependent variable is the change in the number of $\mathrm{HH}$ members who worled outside the $\mathrm{HH}$ by sector. All regressions contain lagged demographic controls and department dummies. All standard errors allow for clustering within municipios. $t$-statistics reported in parentheses. 
Table 12: Adverse Shocks and Hours Worked Outside the HH - Women

\begin{tabular}{|c|c|c|c|c|c|}
\hline & (1) & (2) & (3) & (4) & (5) \\
\hline Harvest Loss & $\begin{array}{c}0.06 \\
(0.31)\end{array}$ & $\begin{array}{c}-0.02 \\
(-0.04)\end{array}$ & $\begin{array}{c}0.01 \\
(0.05)\end{array}$ & $\begin{array}{l}-0.30 \\
(-1.30)\end{array}$ & $\begin{array}{c}-0.16 \\
(-0.59)\end{array}$ \\
\hline Livestock Loss & $\begin{array}{c}0.03 \\
(0.11)\end{array}$ & $\begin{array}{c}-0.54 \\
(-0.62)\end{array}$ & $\begin{array}{c}-0.02 \\
(-0.08)\end{array}$ & $\begin{array}{c}0.17 \\
(0.74)\end{array}$ & $\begin{array}{c}0.27 \\
(0.57)\end{array}$ \\
\hline Earthquake Damage & $\begin{array}{c}-0.01 \\
(-0.47)\end{array}$ & $\begin{array}{c}0.03 \\
(0.40)\end{array}$ & $\begin{array}{c}0.01 \\
(0.16)\end{array}$ & $\begin{array}{c}0.01 \\
(0.38)\end{array}$ & $\begin{array}{c}-0.06 \\
(-1.37)\end{array}$ \\
\hline 2001 Dummy & $\begin{array}{l}-0.09 \\
(-0.41)\end{array}$ & $\begin{array}{l}-0.67 \\
(-1.00)\end{array}$ & $\begin{array}{c}-0.50 \\
(-1.84)\end{array}$ & $\begin{array}{c}-0.04 \\
(-0.18)\end{array}$ & $\begin{array}{c}0.10 \\
(0.33)\end{array}$ \\
\hline$R^{2}$ & 0.0075 & 0.0746 & 0.0264 & 0.0158 & 0.0426 \\
\hline Sector & $\mathrm{Ag}$ & Ind & Com & Serv & Tex \\
\hline Households & 1265 & 1265 & 1265 & 1265 & 1265 \\
\hline
\end{tabular}

${ }^{*}$ This table contains ordered logit estimates where the dependent variable is the change in the number of $\mathrm{HH}$ members who worled outside the $\mathrm{HH}$ by sector. All regressions contain lagged demographic controls and department dummies. All standard errors allow for clustering within municipios. $t$-statistics reported in parentheses. 
Figure 1

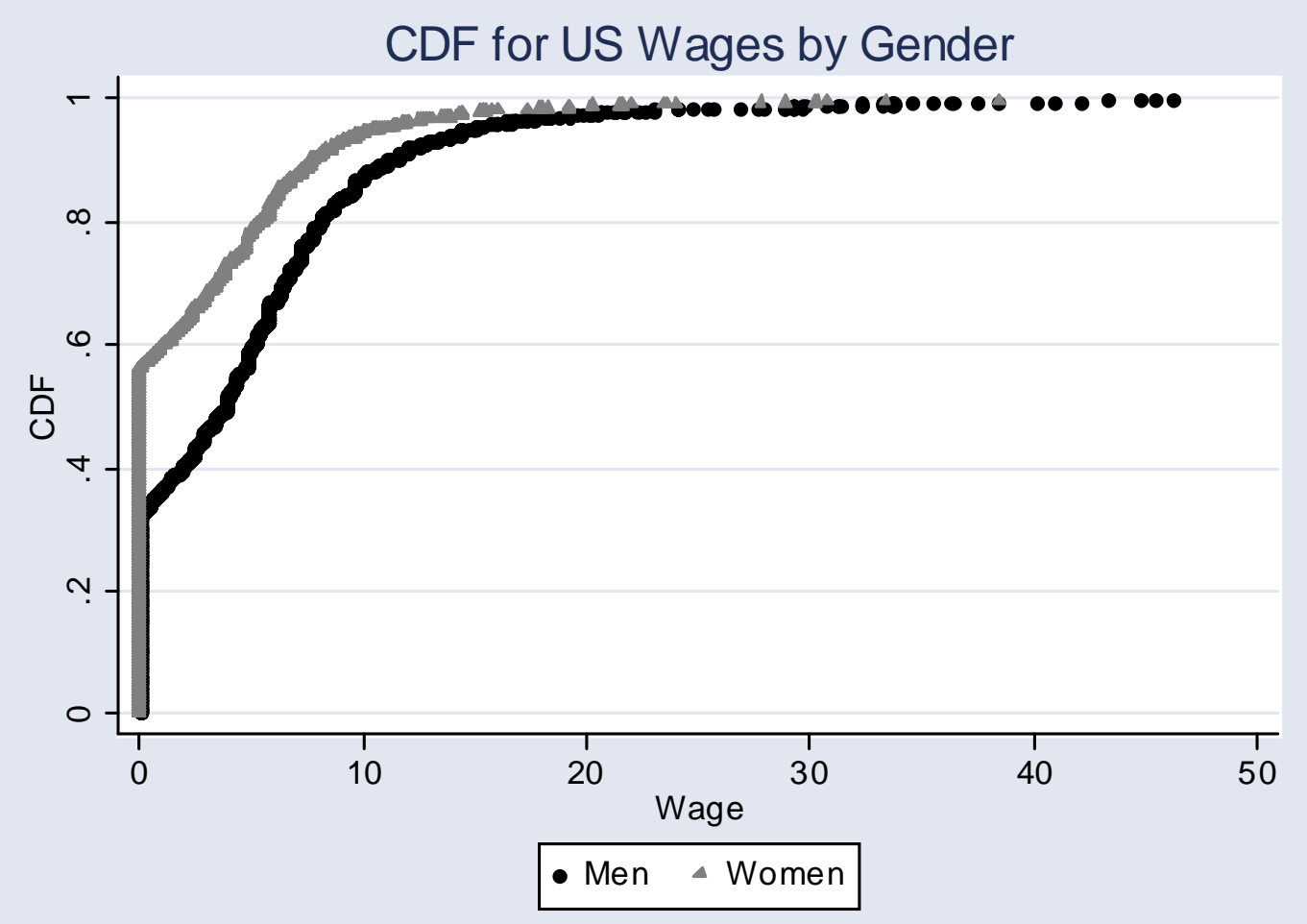


Figure 2

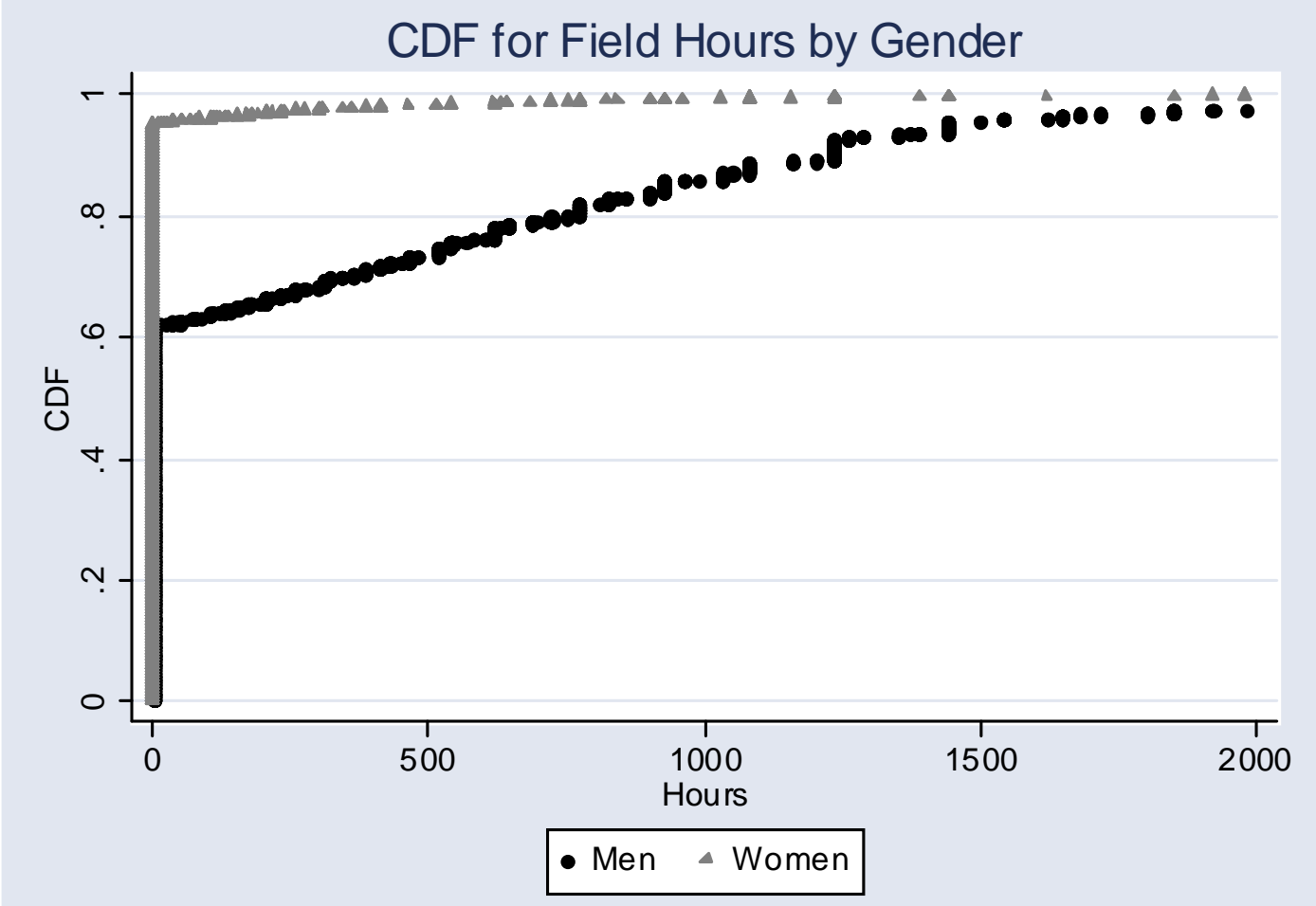


Figure 3

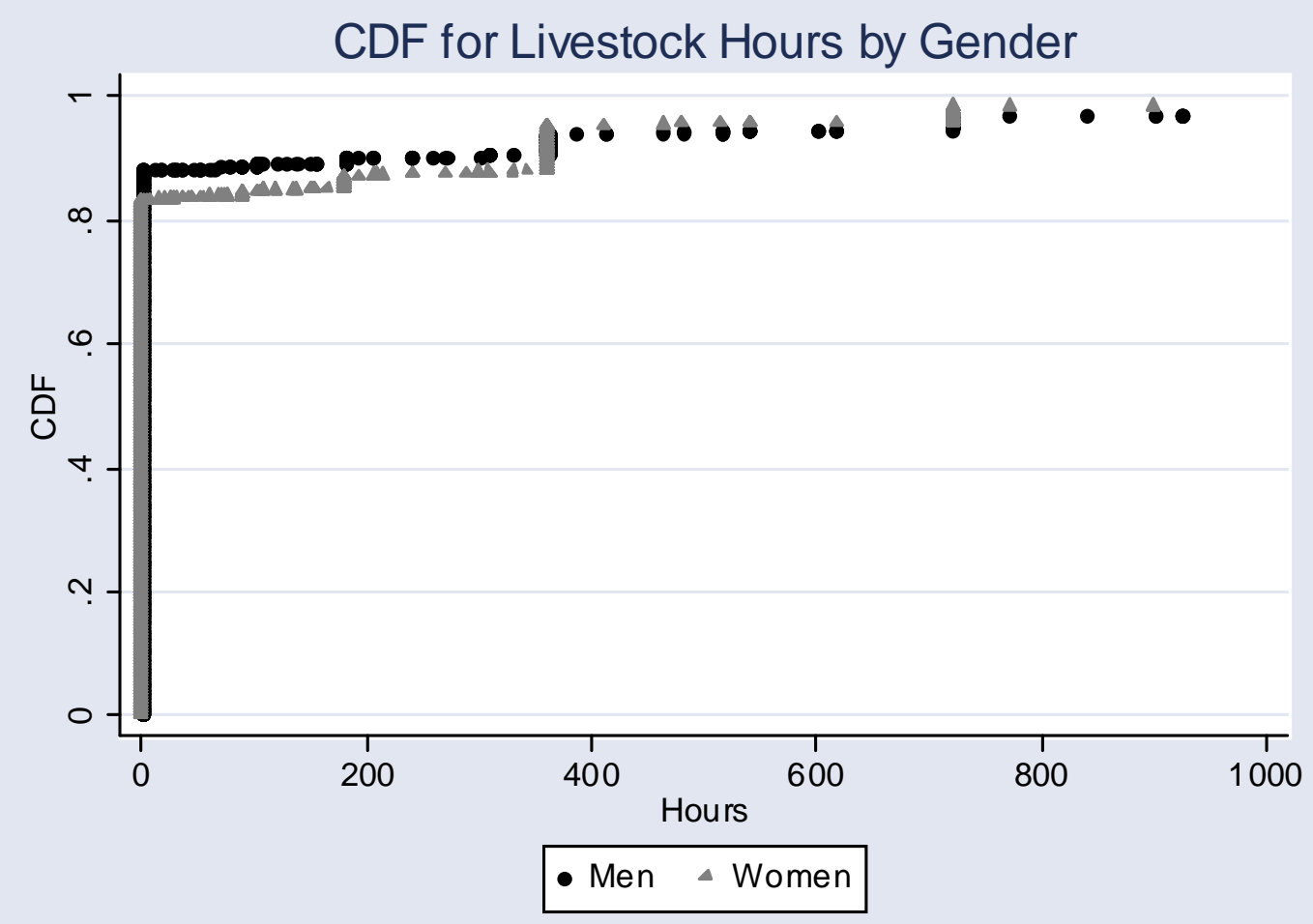


Figure 4

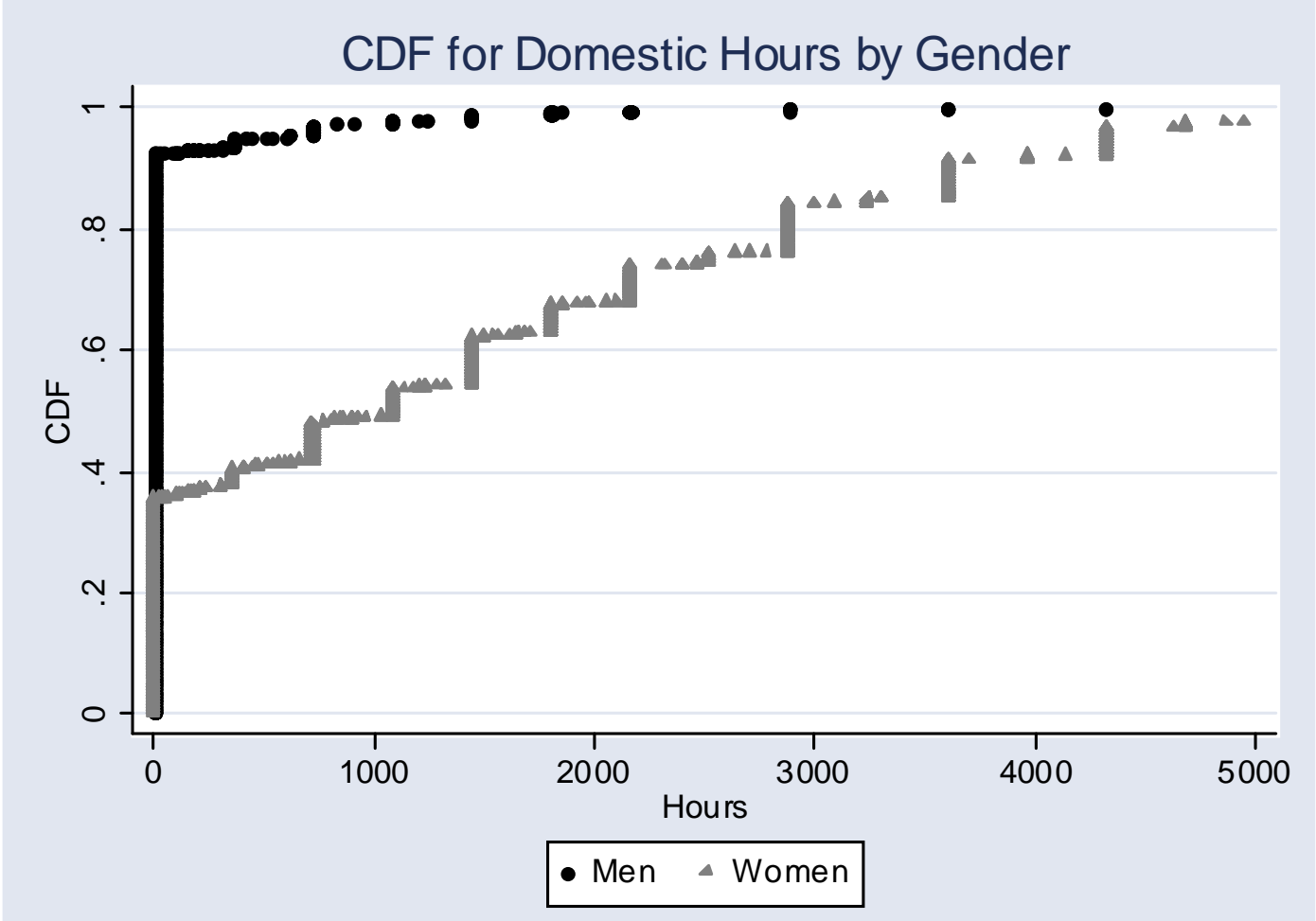

